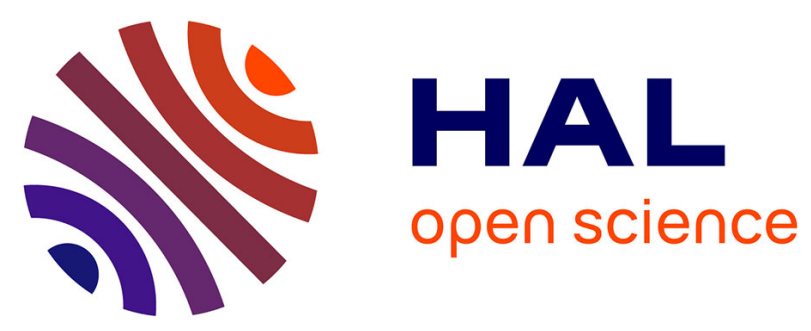

\title{
Extrapair paternity in a German population of the Northern Wheatear ()
}

\author{
Dagmar Kudernatsch, Martin Buchmann, Wolfgang Fiedler, Gernot
}

Segelbacher

\section{- To cite this version:}

Dagmar Kudernatsch, Martin Buchmann, Wolfgang Fiedler, Gernot Segelbacher. Extrapair paternity in a German population of the Northern Wheatear (). Journal für Ornithologie = Journal of Ornithology, 2010, 151 (2), pp.491-498. 10.1007/s10336-009-0486-z . hal-00568366

\section{HAL Id: hal-00568366 https://hal.science/hal-00568366}

Submitted on 23 Feb 2011

HAL is a multi-disciplinary open access archive for the deposit and dissemination of scientific research documents, whether they are published or not. The documents may come from teaching and research institutions in France or abroad, or from public or private research centers.
L'archive ouverte pluridisciplinaire HAL, est destinée au dépôt et à la diffusion de documents scientifiques de niveau recherche, publiés ou non, émanant des établissements d'enseignement et de recherche français ou étrangers, des laboratoires publics ou privés. 


\section{Extrapair paternity in a German population of the Northern Wheatear (Oenanthe oenanthe)}

Dagmar Kudernatsch ${ }^{1}$, Martin Buchmann ${ }^{2}$, Wolfgang Fiedler ${ }^{1}$, Gernot Segelbacher ${ }^{3}$

1) Max-Planck-Institute for Ornithology, Vogelwarte Radolfzell, Schloss Möggingen, Schlossallee 2, D-

78315 Radolfzell, Germany

2) Martin Buchmann, Unterer Sand 12, 55596 Waldböckelheim, Germany

3) Dept. Wildlife Ecology and Management, University Freiburg, Tennenbacher Str. 4,

D-79106 Freiburg, Germany

e-mail: gernot.segelbacher@wildlife.uni-freiburg.de

Tel. +49-761-2038592

Fax +49-761-203

Date of receipt:

Key words: Oenanthe oenanthe - Northern wheatear - microsatellites - extrapair young - brood parasitism

Running title: extrapair paternity in the Northern wheatear 


\begin{abstract}
We here demonstrate the potential of a set of novel microsatellite markers to investigate kin structure and population genetics in the Northern Wheatear (Oenanthe oenanthe). In this study based on 242 individuals from a population in Rhineland-Palatinate (Germany) we found that $26 \%$ of the offspring in $46 \%$ of the broods were sired by other males than the social fathers. We tested different hypotheses why males engage in extrapair copulations and found that almost all identified genetic fathers originated from directly neighbouring territories. Additionally, we detected two out of 134 offspring in two broods that could not be assigned to their putative mother and thus were probably the result of intraspecific brood parasitism.
\end{abstract}




\section{Introduction}

The Northern Wheatear (Oenanthe oenanthe) is a widespread long distance migrating bird species in Europe and its ecological behaviour has been extensively studied (e.g. Arlt and Pärt 2007, 2008; Delingat et al. 2008). Wheatears have been considered to be socially monogamous but already Currie et al. (1998) found that females frequently engage in extrapair copulations (EPC). Such findings have been proved to be common in many other bird species. In more than $75 \%$ of socially monogamous passerine species extrapair young (EPY) could be detected with over $11 \%$ of offspring being sired by an extrapair male (Griffith et al. 2002).

Previous research suggested three main hypotheses for the benefits of such extrapair copulations: (i) the genetic diversity hypothesis (Petrie and Kempenaers 1998), (ii) the good genes hypothesis (Birkhead and Møller 1992) and (iii) the genetic compatibility hypothesis (Johnsen et al. 2000). The genetic diversity hypothesis (i) proposes that females aim to increase the genetic diversity within progeny. This would increase the chance that at least some offspring will survive if environmental conditions change (Yasui 1998, 2001). The hypothesis predicts that EPY are distributed randomly among broods and the population's males (Griffith et al. 2002). The good genes hypothesis and the genetic compatibility hypothesis both argue that females seek EPCs with males of higher quality than their social mates. According to the good genes hypothesis (ii) females seek to gain genes of high quality for their offspring, i.e. genes linked to viable or attractive phenotypes (Westneat et al. 1990, Birkhead and Møller 1992). EPY thus should not be distributed randomly among broods, but be more frequent in broods where the female is paired with a male of low quality (Griffith et al. 2002). Conversely, males with high quality features are predicted to gain extrapair paternity (EPP) more often than males of low quality (Griffith et al. 2002). The sexy son hypothesis links the good genes hypothesis and the sex allocation theory (Trivers and Willard 1973). It predicts a sex-bias among EPY towards males to pass on the attractiveness primarily to the male offspring (Møller and Ninni 1998, Dietrich-Bischoff et al. 2006). In the genetic compatibility hypothesis (iii) females will choose males which best complete the female's genome (Kempenaers et al. 1999, Tregenza and Wedell 2000). The extrapair father's genome is expected to be very dissimilar to the female's, be very heterozygous, and/or carry rare alleles. The resulting offspring would be more heterozygous (Foerster et al. 2003, Stapleton et al. 2007) and be able to express a 
greater number of gene products, e.g. from the major histoncompatibility complex (Johnsen et al. 2000, Fossøy et al. 2007). The hypothesis predicts higher EPP rates in genetically more related pairs, and that the EPF is less related to the female than her social partner (Griffith et al. 2002).

Several studies seem to support the genetic benefits hypotheses (e.g. Johnsen et al. 2000, Foerster et al. 2003) although Akcay and Roughgarden (2007) found that half of the studied species fail to support the good genes and the genetic compatibility hypothesis and moreover, that the type of genetic benefit varies across species, between close related species and even within the same species.

In our study on wheatears we explore the different hypotheses by firstly testing a set of novel microsatellite markers for kinship analysis in this species and by identifying potential EPY in broods. When arriving back from their breeding grounds males generally establish territories a few days before females arrive and both parents care for the young equally (Menzel 1964). Breeding pairs defend their territories aggressively and both, females and males, may expel their equivalent sex (Menzel 1964, Currie et al. 1998). During the period of egg laying males are following females closely (Currie et al. 1998). Despite the social monogamy of the species it still remains unclear why extra pair copulations occur frequently in this species. 


\section{Methods}

\section{Study site and field methods}

242 blood samples were obtained from a northern wheatear population in Rhineland-Palatinate, Germany (approximately $49^{\circ} 30^{\prime} \mathrm{N}, 8^{\circ} 10^{\prime} \mathrm{E}$ ), during the breeding seasons 2005 and 2006 . About 150 breeding pairs nest in a vineyard area of about $15 \mathrm{~km}^{2}$. The breeding pairs are inhomogeneous distributed in the area with a density of up to 38 breeding pairs per $\mathrm{km}^{2}$ (see Buchmann 2001). Breeding birds were trapped with small nest traps when they left their nests, other birds using spring net traps. Breeding birds could be defined with great accuracy as social parents as almost all birds in the population were colour-ringed and parents were recorded at their nests several times during the period of nest building period, incubation and feeding the young (see Buchmann 2001, Buchmann et al. 2009). Measurements for body mass were taken using a spring scale with a precision of $0.1 \mathrm{~g}$. Wing length was measured to the nearest $0.05 \mathrm{~mm}$ using a wing ruler and tarsus length was measured to the nearest $0.5 \mathrm{~mm}$ using a calliper. Age of the birds was estimated by plumage features and birds were classified as second year or older ones. Juveniles were sampled in the nests when they were between 6 and 12 days old (mean $7.4 \pm 1.9$ ). Blood from all birds was taken from the brachial vein and transferred in 1 ml Queen's lysis buffer (Seutin et al. 1991). Some samples were transferred in $1 \mathrm{ml} 70 \%$ Ethanol. All samples were stored at $4^{\circ} \mathrm{C}$ until DNA extraction.

\section{DNA methods}

DNA was extracted from blood according to a standard salt extraction method (Miller et al. 1988) with modifications: (i) The extraction buffer contained 10 mM Tris- $\mathrm{HCl}$ pH 8, 10 mM EDTA pH 8, $200 \mathrm{mM} \mathrm{NaCl}$, (ii) a digestion of $40 \mu \mathrm{l}$ of blood sample was carried out for one hour at $55^{\circ} \mathrm{C}$ in a total volume of $400 \mu 1$ which contained $330 \mu \mathrm{l}$ extraction buffer, $2 \%$ SDS and $10 \mu \mathrm{g} / \mu 1$ Proteinkinase K, (iii) all centrifugation steps were performed at 13,000 rpm for five minutes, (iv) for precipitation one volume cooled Isopropanol was added, followed by a centrifugation step and transfer of the supernatant into a new vessel. The pellet was

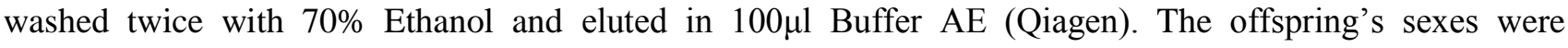
identified using the primers $2550 \mathrm{~F}$ and 2718R (Fridolfsson and Ellegren 1999) in a total volume of $10 \mu \mathrm{l}$ 
containing $1 \mathrm{x}$ mi-Hot Taq-buffer (Metabion), $10 \mathrm{pmol}$ of each primer, $0.2 \mathrm{mM}$ of each nucleotide, $1.5 \mathrm{U}$ miHot-Taq (Metabion) and $1 \mu \mathrm{l}$ of a 1:20 dilution from the stock DNA. The PCR profile comprised an initial denaturation step of $95^{\circ} \mathrm{C}$ for 5 minutes, followed by a touch-down scheme with the annealing temperature being lowered $0.5^{\circ} \mathrm{C}$ per cycle, starting at $54^{\circ} \mathrm{C}$ until $48^{\circ} \mathrm{C}$ was reached. Additional 20 cycles at that temperature were followed by a final step of 5 minutes at $72^{\circ} \mathrm{C}$. PCR products were resolved in $1.2 \%$ agarose gels and stained with SYBR Gold (Invitrogen). Individual genotyping was performed as described in Kudernatsch et al. (2009) for the loci oe2, oe4, oe5, oe6, oe7, oe8, oe9, oe10, oe11, oe12.

\section{Parentage analyses}

In 2005 we sampled 15 complete families with a total of 99 offspring: 77 young hatched in first clutches and 22 young in second clutches from five of the families (overall mean $4.95 \pm 1.1 \mathrm{SD}$, Appendix 1). In 2006 five additional families with first and second broods were sampled. They comprised a total of 35 offspring of which 20 young hatched in first clutches and 15 in second clutches (overall mean $3.89 \pm 1.7$ SD offspring per brood, Appendix 1). For parentage analysis we included additional individuals captured in the breeding area (21 females and 25 males in 2005, 46 males and 8 females in 2006). Based on field observations in our study area we estimated that we sampled about $30 \%$ of all resident males in 2005 and about $50 \%$ in 2006 . When analysing extra pair paternity for males in 2005 we only analysed broods in which the breeding female could be genetically assigned as the mother of the clutch $(n=97)$. Median hatching date for first broods was not different in our sampled broods as compared to the whole study population (1995: median 18.5. for population ( $\mathrm{n}=37)$, median for sampled broods 17.5. $(\mathrm{n}=15))$.

For loci oe2, oe9, and oe11 the presence of possible null alleles can't be ruled out (see Kudernatsch et al. 2009) which might result in false exclusion of paternity. To assign offspring genotypes to the parents' genotypes, individuals with only one band at these loci were therefore not regarded as homozygotes, but as heterozygotes with one unknown loci (indicated by a zero). Parentage was determined using the likelihood based approach in CERVUS 3.0 (Kalinowski et al. 2007, available at http://www.fieldgenetics.com). First, we 
assessed maternity and if confirmed, mothers were included into the offspring file as known parent. Exclusion probability was very high (> 0.999). An individual was assigned as the genetic father, if the probability values estimated by CERVUS suggested it with a confidence level of at least $80 \%$ or if the social father had the highest LOD score of all potential male birds tested. The chosen confidence level describes that at least $80 \%$ of the parentage assignments are reliably correct.

\section{Heterozygosity and genetic similarity}

Standardized heterozygosity was calculated for each individual (see Coltman et al. 1999). Genetic similarity between individuals was calculated using the method of Queller and Goodnight (1998) implemented in the IDENTIX 1.1 software (Belkhir et al. 2002, http://www.genetix.univ-montp2.fr). The loci oe2, oe9 and oe11 were excluded for the calculation of genetic similarity and heterozygosity because of the possible presence of null alleles.

\section{Statistical analyses}

Statistical analyses were performed using the R 2.5.1 software (R Development Core Team 2007, http://www.r-project.org). Data from 2005, 2006 and both seasonal broods were pooled for all analyses. The distribution of EPP among broods was analysed as described in Bouwman et al. (2007), based on Sokal and Rohlf (1994) and Perreault et al. (1997). We compared the heterozygosity of within-pair young (WPY) with that of their maternal half-siblings using a generalised linear mixed model (GLMM, Laplace method). Family identity was included as a random factor and the status of offspring (WPY or EPY) as a fixed factor. Heterozygosity, the response variable, was considered as proportion data and handled as described in Crawley (2007). High levels of overdispersion made a modification of the model with quasi-binomial rather than binomial errors necessary. We compared males in parameters of body size and body condition. It proved that body size is better represented by a combination of parameters rather than solely by univariate variables

(Freeman and Jackson 1990). Therefore we conducted a principal components analysis including measurements of tarsus and wing length. Values of the first ordinary axis were determined as 'body size' for 
all individuals. Since the data of tarsus and wing length was not scaled identically, a correction factor integrated in $\mathrm{R}$ was applied. The body condition of males was calculated as residuals from ordinary least squares of body mass versus body size (Figure 1; see Schulte-Hostedde et al. 2005). Rare alleles were determined by first calculating frequencies for each allele per locus using the Genepop 4.0 software (Raymond and Rousset 1995, http://genepop.curtain.edu.au). Allele frequencies were root transformed to converge a binomial distribution. . We identified the first quartiles of the frequencies at each locus and considered alleles as 'rare' if their frequency was less than the value of the first quartile. First quartiles of allele frequencies per locus were identified using the summary option in R. 


\section{Results}

\section{Parentage analyses}

In total, $26 \%$ of offspring were not the genetic offspring of their social fathers. Split in both years EPP-rate was $25 \%$ (24/97) in 2005 and $29 \%(10 / 35)$ in 2006. At least one EPY occurred in $46 \%$ of the broods, comprising 50\% (10/20) of broods in 2005 and 38\% (3/8) of broods in 2006. Genetic fathers could be assigned for 42\% of EPY in 2005 (12 offspring in 5 broods) and for 30\% of EPY in 2006 (3offspring in 3 broods).

We identified two clutches in which one of the nestlings genetically did not match the female of the breeding pair. Both cases were observed in second broods 2005. In one of the cases both genetic parents could be assigned and their territory was located about 300 metres away from the nest site with two other territories being located in between.

\section{Test of the genetic benefits hypotheses}

Distribution of EPY among broods:

EPY were not allocated randomly among broods: the distribution significantly deviated from a binomial

distribution (Table $1, \chi^{2}=32.19$, d.f. $=7, \mathrm{p}<0.001$ ). Twice as many broods as expected did not contain any EPY. Only a few broods contained one or two EPY. There were more broods than expected which contained numerous EPY (Table1).

\section{Distribution of EPF among broods:}

Four females chose only one male in addition to their pair male as the father for their offspring. Several males were chosen as EPF's in another four broods. One male bird was especially successful in obtaining EPC's: Besides being a father in his own brood he was also the father of young in two other broods. In his own brood only one out of three young was sired by him. 


\section{Spatial analysis of potential fathers}

The distance between the territory of extrapair male and the nesting site of the female was less than 500 metres (mean $250 \mathrm{~m} \pm 150 \mathrm{~m} \mathrm{SD}, \mathrm{n}=7$ ) in all cases except for one. The EP father usually originated from directly neighbouring territories $(n=6)$. In one case the territory of the EP father located 2,550 metres away from the female's nesting site.

\section{Genetic similarity, heterozygosity and rare alleles:}

We found a significant negative correlation between the genetic similarity of parents and the heterozygosity of their young, i.e. genetically dissimilar parents produced more heterozygous young than genetically similar parents (Pearson's product-moment correlation; $\mathrm{t}=-2.37, \mathrm{p}=0.03, \mathrm{n}=27$ mate combinations). Yet, EP fathers were not more dissimilar to females than their social mates (Wilcoxon matched pairs test, $\mathrm{V}=18, \mathrm{p}=0.73, \mathrm{n}=$ 8 dyads, Figure $2 a$ ), nor were they more heterozygous than WPF's (Wilxocon matched pairs test, V=15, $\mathrm{p}=0.73, \mathrm{n}=8$ dyads). Congruously, the WPY did not differ in heterozygosity from their maternal half-sibs (GLMM, $\chi^{2}=0.98$, d.f. $=1, \mathrm{p}=0.32, \mathrm{n}=10$ dyads) and their paternal half-sibs (GLMM, $\chi^{2}=0.47$, d.f. $=1$, $\mathrm{p}=0.49, \mathrm{n}=4$ dyads). The heterozygosity of WPY and EPY is compared in Figure $2 b$. EP fathers did not display more rare alleles than within the breeding pair (Wilcoxon matched pairs test, $\mathrm{V}=1.5, \mathrm{p}=0.57$ ).

\section{Are fatter, larger and older males sexier?}

EP fathers tended to be larger than males of the breeding pair (Wilcoxon's matched pairs test, $V=5, p=0.08, n$ $=8$ dyads, Figure $2 c$ ). Male social mates in families without EPP were not larger than in families with EPP occuring (Wilcoxon signed rank test, $\mathrm{W}=56, \mathrm{p}=0.65, \mathrm{n}=9$ without EPY, 11 with EPY). The body condition of EPF's did not differ from that of WPF's (Wilcoxon's matched pairs test, V=10, $\mathrm{p}=0.31, \mathrm{n}=8$ dyads, Figure 2d). The age of males does not explain the occurrence of EPP: Males of the second calendar year were betrayed as often as older ones $\left(\chi^{2}=1.36\right.$, d.f. $\left.=7, p=0.99, n=8\right)$. Nevertheless, females with young mates as breeding partners more often choose older males for EPC $(n=4$ out of 5$)$ and never choose younger ones 
when breeding with an older male ( $\mathrm{n}=3$ old males). Old males in the population were significantly larger than young males (Wilcoxon signed rank test, $\mathrm{W}=61, \mathrm{p}<0.001, \mathrm{n}=15$ young, 27 old males).

\section{Sex allocation theory:}

The entire data set comprised 134 nestlings of the northern wheatear. Overall sex ratio was insignificantly biased towards females (46\% males; Wilcoxon signed rank test, $\mathrm{W}=167, \mathrm{p}=0.18$ ). In broods containing EPY and WPY, there was no bias towards one sex in EPY compared to their maternal half sibs (Wilcoxon's matched pairs test, $\mathrm{V}=28, \mathrm{p}=0.55, \mathrm{n}=11$ dyads, Figure $3 a$ ). However, broods which contained no EPY displayed significantly more females than broods with a combination of EPY and WPY (Wilcoxon signed rank test, $\mathrm{W}=85, \mathrm{p}=0.04, \mathrm{n}=11$ for broods only containing WPY, $\mathrm{n}=10$ for broods containing at least some EPY, Figure $3 b)$.

Is there a seasonal difference in EPP rates?

In all families except one we found equal or insignifcantly lower EPP rates in the second brood of the year (Wilcoxon's matched pairs test, $\mathrm{V}=22.5, \mathrm{p}=0.18, \mathrm{n}=10$ dyads). 


\section{Discussion}

\section{Frequency of extra - pair offspring}

The EPP rates of the northern wheatear in this study (29\% of offspring in $46 \%$ of broods) are above the mean value for socially monogamous birds (11\% of offspring in $29 \%$ of broods, Griffith et al. 2002). Interestingly our results exceed those of an earlier study in the northern wheatear (11\%, n= 73 offspring, Currie et al. 1998). Currie et al. (1998) were studying birds on Bardsey Island, which is located three kilometres of the mainland's coast. EPP rates are often unexpectedly low within island populations probably due to lower sexual selection processes (Griffith 2000) or to genetic depletion. However, a higher density of birds (27 territory males/100ha on Bardsey Island, up to 38 males/100ha in our study area) may have also been led to higher EPY rates in our study area.

\section{Genetic diversity hypothesis}

The genetic diversity hypothesis predicts that females aim to mate with multiple males and that EPP is distributed randomly among broods. In support of the hypothesis, we found that some females chose more than one male as the father for EPY. On the other hand, a similar number of females chose only single males as fathers for EPY. This tends to support the good genes and the genetic compatibility hypotheses, but opposes the genetic diversity hypothesis. Another contradictory result is that EPY were not distributed among broods randomly. The most crucial factor to reject the genetic diversity hypothesis is that EPY were not more heterozygous than WPY. However, Most of the studies on EPP in birds found only weak evidence for this hypothesis (Kempenaers et al. 1999) or evidence to reject the hypothesis (e.g. Bouwman et al. 2006, Ockendon et al. 2009).

\section{Good genes hypothesis}

The good genes hypothesis predicts that EP Males are of higher quality, which might be reflected by larger body mass, age or attractive plumage features. In our study, we did not find better body conditions in extrapair males, i.e. they did not have larger body mass. This contradicts the results of Currie et al. (1998), which stated 
that males with a better body condition are preferred based on 8 broods with genetic and social fathers known. Contradictory relations within the same species have been described before (e.g. Kempenaers et al. 1997, Charmantier et al. 2004), and this might indicate that study sites differ and not all females may choose the same criteria (compare Aksay and Roughgarden 2007).

We did not find differences in EPP rates in nests of young and old territory males. Old males were larger than young males; but body size and age are not independent factors.

There was no sex bias towards one sex in the young northern wheatears. The sex ratio in broods which contained EPY and WPY was equal, too. However, broods without EPY tended to contain more females. However, this bias in our study needs to be evaluated with a larger sample size as the direction of sex allocation differs between species and even between populations of the same species (reviewed in Komdeur and Pen 2002). Nestling mortality could not be detected in our study area (number of eggs matched always the number of hatched young).

\section{Genetic compatibility hypothesis}

Females, which follow the genetic compatibility hypothesis are supposed to choose extrapair males which are genetically more dissimilar, very heterozygous and/or carry rare alleles. But those criteria did not influence the female's mate choice in our study. Thus, we reject the hypothesis for the northern wheatear in the studied population. However, it has recently suggested that females selecting genetically compatible fathers for their offspring offer a possible general explanation for the function of extrapair paternity (Griffith and Immler 2009).

\section{Sexy neighbours}

In this study, EP males usually originated from directly neighbouring territories. Several studies documented similar findings (e.g. Perreault 1997, Kempenaers 1999, Johnsen et al. 2000, Segelbacher et al. 2005, Bouwman et al. 2007, Garvin et al. 2006), suggesting that females may gain non-genetic benefits from extrapair males, e.g. additional hunting grounds, participation in raising the young or anti-predator defence 
(Møller and Ninni 1998). Males residing at nearby territories might on the other hand just have more chances to approach the female for an EPC than males from more distant territories. If neighbouring males have more chances to court a female than other males of more distant territories do, then pair males do basically only compete against neighbouring males in terms of attractiveness instead of competing against the most attractive males in the whole population. Therefore it can be assumed that extrapair males do not necessarily need to be more attractive than the neighbouring female's social mate's to successfully obtain extrapair offspring.

\section{Intraspecific brood parasitism}

We detected two individual offspring which were not genetically not matching the female of the breeding pair. This could be explained by potential intraspecific brood parasitism. Additional support for such a behaviour comes from field observations, where females were observed to aggressively expell other females from their territories. This might be a reaction in order to keep them from laying an egg into their clutch. We have observed the breeding male and female during the breeding period several times at their nest (nest building, incubating, feeding) and thus assume that any potential errors in catching non breeding birds and misclassifying the mother of the clutch are very low in the our described cases.

In our study we demonstrate the potential of a novel set of microsatellite markers to investigate the breeding biology of wheatears. Although our sampling size is relatively small to test the different hypotheses in detail, we are convinced that further studies will have the potential to fully explore these questions data using our marker set. 


\section{Fremdvaterschaften und Brutparasitismus beim Steinschmätzer}

\section{Zusammenfassung}

In einer Population von Steinschmätzern (Oenanthe oenanthe) in Rheinland Pfalz führten wir Vaterschaftsanalysen an 242 Individuen mit neuen genetischen Mikrosatellitenmarker durch. In $46 \%$ aller untersuchten Nester fanden wir Jungvögel, die nicht vom Männchen des Brutpaars gezeugt wurden. Insgesamt konnten 26\% aller Jungvögel auf andere Männchen zurückgeführt werden. Außerdem konnten wir in zwei Nestern Jungvögel beobachten, die nicht vom brütenden Weibchen stammten und damit wahrscheinlich ein

Ergebnis von Nestparasitismus sind. Wir testeten verschieden Hypothesen warum Weibchen Fremdvaterschaften suchen und fanden fast alle nachgewiesenen Väter in direkt benachbarten Territorien. 


\section{References}

Akçay E, Roughgarden J (2007) Extrapair paternity in birds: review of the genetic benefits. Evolutionary Ecology Research 9: 855-868.

Arlt D, Part T (2007) Nonideal breeding habitat selection: A mismatch between preference and fitness. Ecology 88, 792-801.

Arlt D, Part T (2008) Post-breeding information gathering and breeding territory shifts in northern wheatears. Journal of Animal Ecology 77: 211-219.

Belkhir K, Castric V, Bonhomme F (2002) IDENTIX, a software to test for relatedness in a population using permutation methods. Molecular Ecology Notes 2: 611-614.

Bennet PM, Owens IPF (2002) Evolutionary Ecology of Birds: Life History, Mating Systems and Extinction. Oxford University Press, Oxford, UK.

Birkhead TR, Møller AP (1992) Sperm Competition in Bird. Academic Press, London, UK.

Bouwman KM, Burke T, Komdeur J (2006) How female reed buntings benefit from extrapair mating behaviour: testing hypotheses through patterns of paternity in sequential broods. Molecular Ecology $15: 2589-2600$.

Bouwman KM, Van Dijk RE, Wijmenga JJ, Komdeur J (2007) Older male reed buntings are more successful at gaining extrapair fertilizations, Animal Behaviou:, 73, 15-27.

Brooks R, Kemp DJ (2001) Can older males deliver the good genes. Trends in Ecology \& Evolution 16: 308313.

Buchmann M (2001) Die Brutbiologie des Steinschmätzers (Oenanthe oenanthe) auf intensiv genutzen Flächen in Rheinland-Pfalz. Die Vogelwarte 41: 1-17.

Buchman M, Helm B, Rothery P, Flinks H (2009) Auswirkungen von Spätbruten auf Mauser und Rückkehrrate bei einem Weitstreckenzieher, dem Steinschmätzer (Oenanthe oenanthe). Die Vogelwarte 47: 125-133. 
Charmantier A, Blondel J, Perret P, Lambrechts MM (2004) Do extrapair paternities provide genetic benefits for female blue tits Parus caeruleus? Journal of Avian Biolog 35: 524-532.

Cohas A, Yoccoz NG, Allainé D (2007) Extrapair paternity in alpine marmots, Marmota marmota: genetic quality and genetic diversity effects. Behavioral Ecology and Sociobiology 61: 1081-1092.

Coltman DW, Pilkington JG, Smith JA, Pemberton JM (1999) Parasite-mediated selection against inbred Soay sheep in a freeliving island population. Evolution 53: 1259-1267.

Crawley MJ (2007) The R Book. John Wiley \& Sons Ltd, West Sussex,U.K.

Currie DR, Burke T, Whitney RL, Thompson DBA (1998) Male and female behaviour and extrapair paternity in the wheatear. Animal Behaviour 55: 689-703.

Currie DR, Krupa AP, Burke T, Thompson DBA (1999) The effect of experimental male removals on extrapair paternity in the wheatear, Oenanthe oenanthe, Animal Behaviour 57: 145-152.

Delingat J, Bairlein F, Hedenstrom A (2008) Obligatory barrier crossing and adaptive fuel management in migratory birds: the case of the Atlantic crossing in Northern Wheatears (Oenanthe oenanthe). Behavioral Ecology and Sociobiology, 62, 1069-1078.

Dietrich-Bischoff VD, Schmoll T, Winkel W, Krackow S, Lubjuhn T (2006) Extrapair paternity, offspring mortality and offspring sex ratio in the socially monogamous coal tit (Parus ater). Behavioral Ecology and Sociobiology 60: 563-571.

Foerster K, Delhey K, Johnsen A, Lifjeld JT, Kempenaers B (2003) Females increase offspring heterozygosity and fitness through extrapair matings. Nature 425: 714-717.

Fossøy F, Johnsen A, Lifjeld JT (2007) Multiple genetic benefits of female promiscuity in a socially monogamous passerine. Evolution 62: 145-156.

Freeman S, Jackson WM (1990) Univariate Metrics Are Not Adequate to Measure Avian Body Size. The Auk 107: 69-74.

Fridolfsson AK, Ellegren H (1999) A simple and universal method for molecular sexing of non-ratite birds. Journal of Avian Biology 30: 116-121. 
Garvin JC, Abroe B, Pedersen MC, Dunn PO, Whittingham LA (2006) Immune response of nestling warblers varies with extrapair paternity and temperature. Molecular Ecology 15: 3833-3840.

Griffith SC, Owens IP, Thuman KA (2002) Extra pair paternity in birds: a review of interspecific variation and adaptive function. Molecular Ecology 11: 2195-2212.

Griffith SC, Immler S (2009) Female infidelity and genetic compatibility in birds: the role of the genetically loaded raffle in understanding the function of extrapair paternity. Journal of Avian Biology 40: 97-101.

Hutchinson JMC, Griffith SC (2008) Extrapair paternity in the Skylark Alauda arvensis. Ibis 150: 90-97.

Johnsen A, Andersen V, Sunding C, Lifjeld JT (2000) Female bluethroats enhance offspring immunocompetence through extrapair copulations. Nature 406: 296-299.

Johnsen A, Lifjeld JT, Krokene C (2003) Age-Related Variation in Mate-Guarding Intensity in the Bluethroat (Luscinia s. svecica). Ethology 109: 147-158.

Kalinowski ST, Taper ML, Marshall TC (2007) Revising how the computer program CERVUS accomodates genotypic error increases success in paternity assignment. Molecular Ecology 16: 1099-1106.

Kempenaers B, Congdon B, Boag P, Robertson RJ (1999) Extrapair paternity and egg hatchability in tree swallows: evidence for the genetic compatibility hypothesis? Behavioral Ecology 10: 304-311.

Komdeur J, Pen I (2002) Adaptive sex allocation in birds: the complexities of linking theory and practice. Philosophical Transections of the Royal Society of London, Series B 357: 373-380.

Kudernatsch D, Weis-Dootz T, Segelbacher G (2009) Isolation of ten tetranucleotide microsatellite loci in the Northern Wheatear (Oenanthe oenanthe). Molecular Ecology Ressources 9:542-543.

Menzel H (1964) Die neue Brehm Bücherei - Der Steinschmätzer (Oenanthe oenanthe). Ziemsen Verlag, Wittenberg Lutherstadt, Germany.

Miller SA, Dykes DD, Polesky HF (1988) A simple salting out procedure for extracting DNA from human nucleated cells. Nucleic Acids Research 16: 1215.

Møller AP, Ninni P (1998) Sperm competition and sexual selection: a meta-analysis of paternity studies in birds. Behavioral Ecology and Sociobiology 43: 345-358. 
Ockendon N, Griffith SC, Burke T (2009) Extrapair paternity in an insular population of house sparrows after the experimental introduction of individuals from the mainland. Behavioural Ecology 20: 305-312

Perreault S, Lemon RE, Kuhnlein U (1997) Patterns and correlates of extrapair paternity in American redstarts (Setophaga ruticilla). Behaviroal Ecology 8: 612-621.

Petrie M, Kempenaers B (1998) Extrapair paternity in birds: explaining variation between species and populations. Trends in Ecology and Evolution 13: 52-58.

Queller DC, Goodnight KF (1989) Estimating relatedness using genetic markers. Evolution, 43, 258-275.

R Development Core Team (2003) R: a language and environment for statistical computing. R Foundation for Statistical Computing, Vienna

Raymond M, Rousset F (1995) GENEPOP (Version 1.2): population genetics software for exact tests and ecumenicism. Journal of Heredity 86: 248-249.

Schulte-Hostedde AI, Zinner B, Millar JS, Hickling GJ (2005) Restitution of mass-size residuals: Validating body condition indices. Ecology 86: 155-163.

Segelbacher G, Kabisch D, Stauss M, Tomiuk J (2005) Extrapair young despite strong pair bonds in the European Nuthatch (Sitta europaea). Journal of Ornithology 146: 99-102.

Seutin G, White BN, Boag PT (1991) Preservation of avian blood tissue samples for DNA analysis. Canadian Journal of Zoology 69: 82-90.

Sokal R, Rohlf FJ (1994) Biometry, 3rd edn. W.H. Freeman, New York. Stutchbury BJ, Rhymer JM, Morton ES (1994) Extrapair paternity in hooded warblers. Behavioral Ecology, 5, 384-392.

Stapleton MK, Kleven O, Lifjeld JT, Robertson RJ (2006) Female tree swallows (Tachycieneta bicolor) increase offspring heterozygosity through extrapair mating. Behavioral Ecology and Sociobiology 16: $1725-1733$.

Tregenza T, Wedel, N (2000) Genetic compatibility, mate choice and patterns of parentage: Invited Review. Molecular Ecology 9: 1013-1027.

Trivers RL, Willard DE (1973) Natural Selection of Parental Ability to Vary the Sex Ratio of Offspring. Science 179: 90-92. 
Westneat DF, Sherman PW, Morton ML (1990) The ecology and evolution of extrapair copulations in birds. In: Current Ornithology, (ed. Power DM), pp. 331-369. Plenum Press, New York, USA.

Westneat DF, Stewart IRK (2003) Extrapair Paternity in Birds: Causes, Correlates, and Conflict. Annual Review of Ecology, Evolution, and Systematics 34: 365-396.

Yasui Y (1998) The 'genetic benefits' of female multiple mating considered. Trends in Ecology \& Evolution 13: $246-250$.

Yasui Y (2001) Female multiple mating as a genetic bet-hedging strategy when mate choice criteria are unreliable. Ecological Research 16: 605-616.

Yom-Tov Y (2001) An updated list and some comments on the occurrence of intraspecific nest parasitism in birds. Ibis 143: 133-143. 
Table 1Distribution of extrapair young (EPY) among broods of different sizes. Shown are the observed values and the expected values for a binomial distribution (in brackets). There was a divergence from binomial distribution: $\chi=32.19$, d.f. $=7, \mathrm{p}<0.001$.

\begin{tabular}{|c|c|c|c|c|c|c|c|c|c|}
\hline \multirow[b]{2}{*}{ Brood size } & \multicolumn{8}{|c|}{ Number of EPY per brood } & \multirow{2}{*}{$\begin{array}{r}\text { Number of } \\
\text { broods }\end{array}$} \\
\hline & $\mathbf{0}$ & 1 & 2 & 3 & 4 & 5 & 6 & 7 & \\
\hline 3 & $1(1.2)$ & $0(1.3)$ & $2(0.5)$ & $0(0.1)$ & - & - & - & - & 3 \\
\hline 4 & $5(3.3)$ & $3(4.6)$ & $1(2.4)$ & $1(0.6)$ & $1(0.05)$ & - & - & - & 11 \\
\hline 5 & $2(1.3)$ & $0(2.3)$ & $0(1.6)$ & $3(0.6)$ & $0(0.1)$ & $1(0.01)$ & - & - & 6 \\
\hline 6 & $5(1.1)$ & $1(2.4)$ & $0(2.1)$ & $1(1.0)$ & $0(0.26)$ & $0(0.04)$ & $0(0)$ & - & 7 \\
\hline 7 & $1(0.1)$ & $0(0.3)$ & $0(0.3)$ & $0(0.2)$ & $0(0.06)$ & $0(0.01)$ & $0(0)$ & $0(0)$ & 1 \\
\hline Total & $14(7.1)$ & $4(11)$ & $3(7)$ & $5(2.4)$ & $1(0.48)$ & $1(0.06)$ & $\mathbf{0}(\mathbf{0})$ & $\mathbf{0}(\mathbf{0})$ & 28 \\
\hline
\end{tabular}




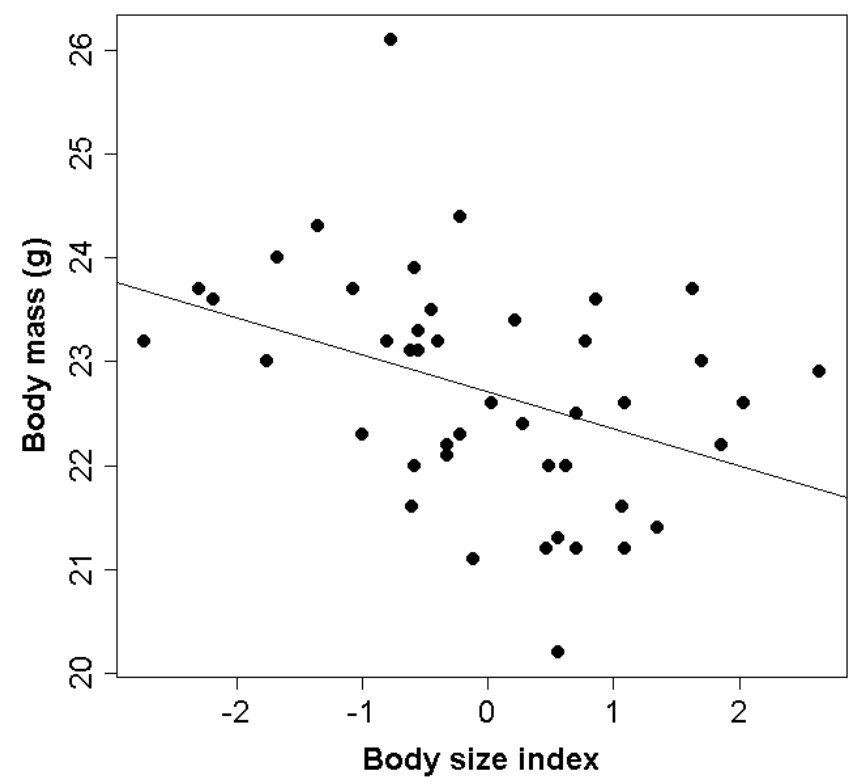

Figure 1

Relationship between body mass and body size for males $\left(r^{2}=0.15, P=0.009, n=44\right)$. The body size index was obtained from a principal component analysis based on tarsus and wing length. 
(a)

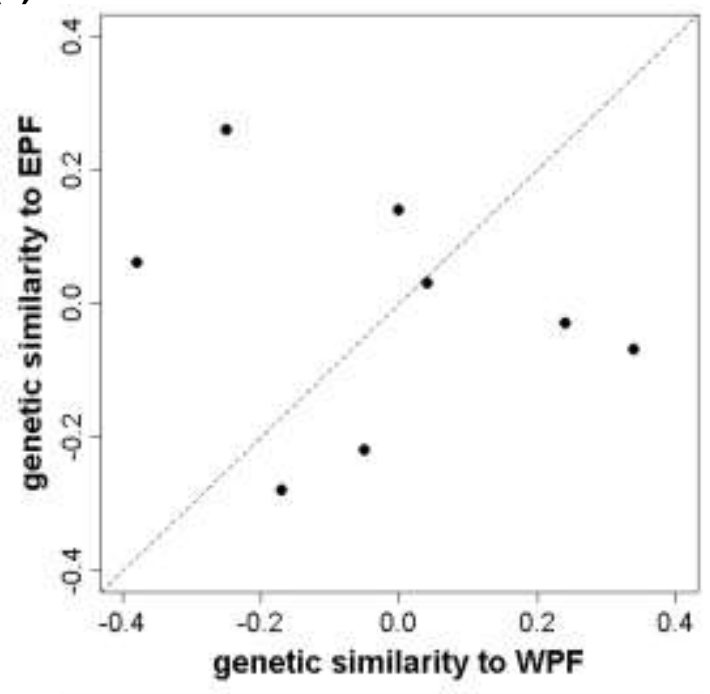

(c)

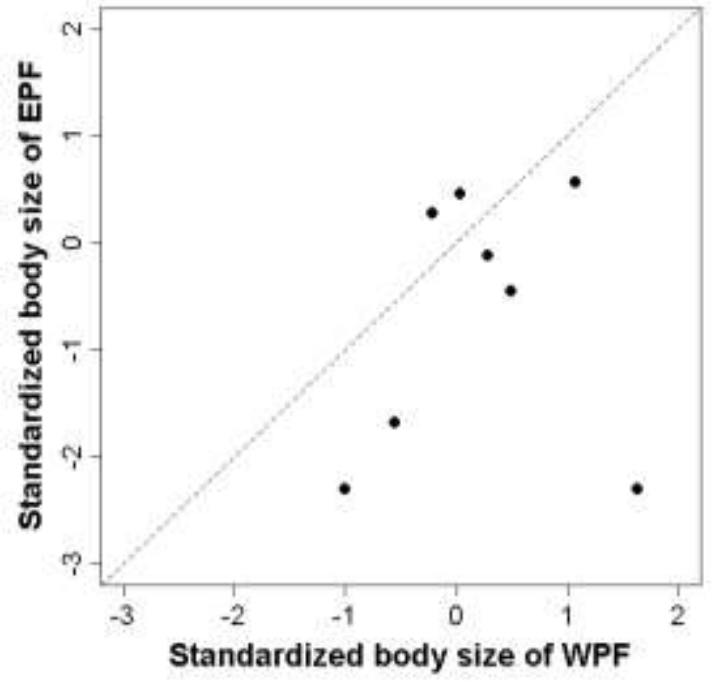

(b)

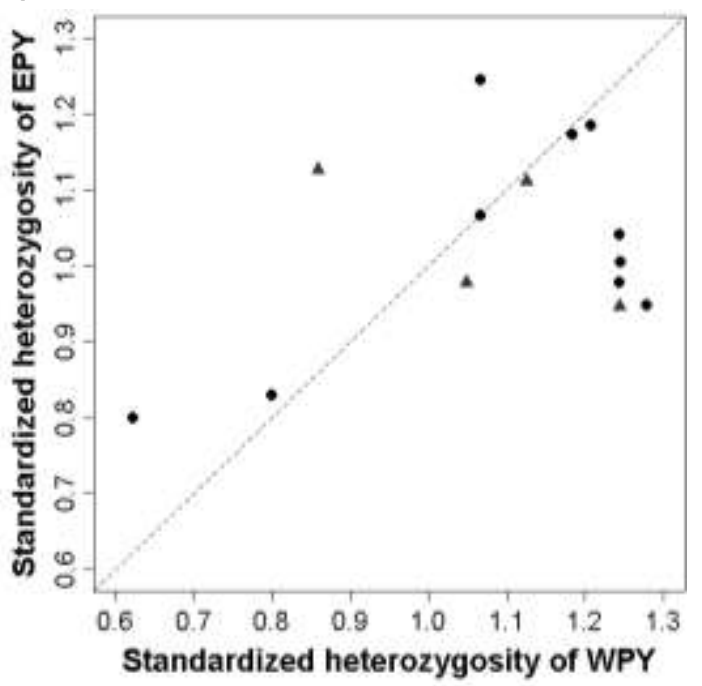

(d)

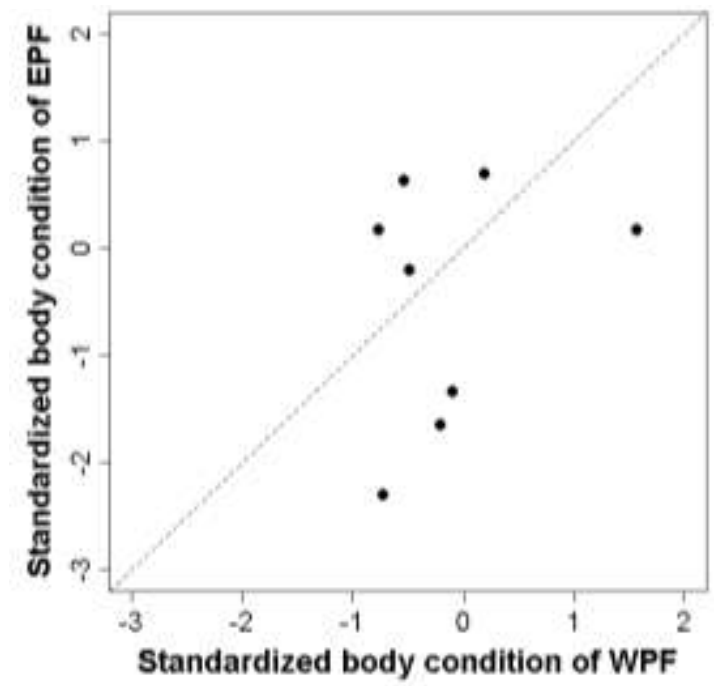

\section{Figure 2}

Pairwise comparisons between (a) genetic similarity of females to within-pair (WPF) and extrapair fathers (EPF); (b) standardized heterozygosity of extrapair young (EPY) and within-pair young (WPY) for maternal (dots) and paternal (triangles) half-sibs; (c) standardized body size of half-sibs; (d) standardized body condition of WPF's and EPF's. 
(a)

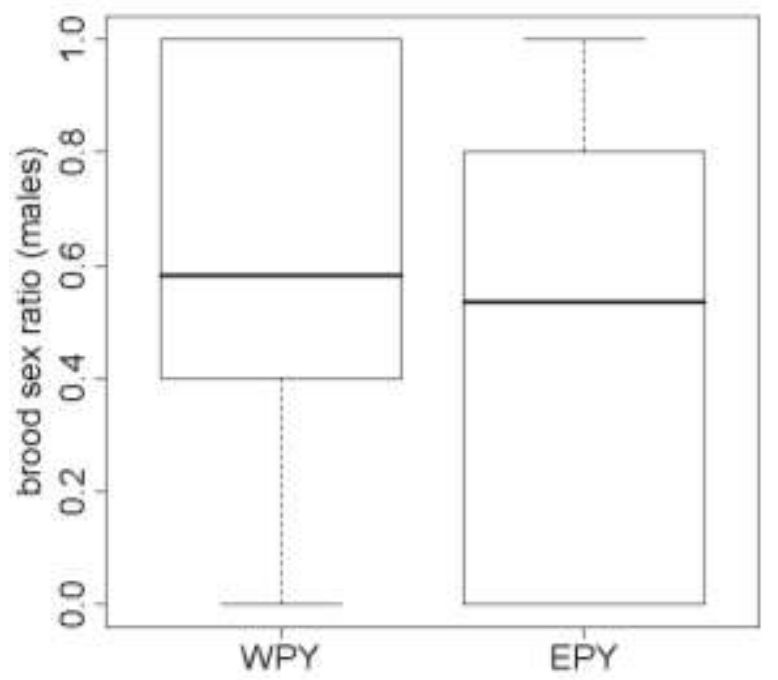

(b)

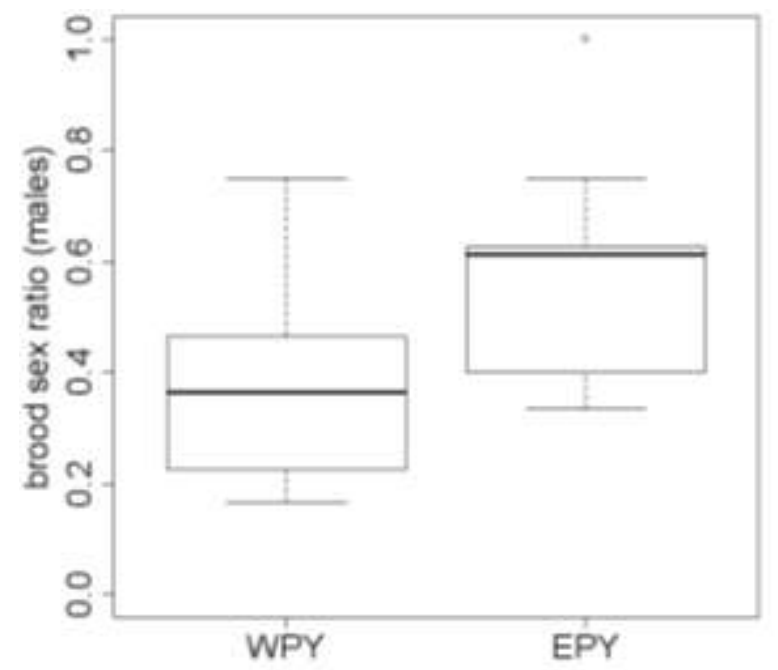

Figure 3 Boxplots showing the brood sex ratio for within-pair young (WPY) and extrapair young (EPY) in (a) broods containing both, WPY and EPY ( $\mathrm{n}=10$ broods), $(b)$ broods which only contained WPY $(\mathrm{n}=11$ broods) and broods which also contained EPY ( $\mathrm{n}=10$ broods). Each boxplot shows the median (horizontal bold line inside box), 25th and 75th percentiles (ends of the box) and 10th and 90th percentiles (ends of dashed lines). 
Appendix 1. List of families included in this study. Presented are the year of sampling, the number of offspring and extrapair young (EPY) in first and second broods. The broods in which juveniles were detected which did not match the putative female are indicated with an asterisk.

\begin{tabular}{|c|c|c|c|c|c|}
\hline \multirow[b]{2}{*}{ family } & \multirow[b]{2}{*}{ year } & \multicolumn{2}{|c|}{ first brood } & \multicolumn{2}{|c|}{ second brood } \\
\hline & & $\mathbf{N}$ offspring & N EPY & N offspring & N EPY \\
\hline 1 & 2005 & 6 & 0 & 0 & 0 \\
\hline 2 & 2005 & 6 & 1 & 0 & 0 \\
\hline 3 & 2005 & 6 & 0 & 0 & 0 \\
\hline 4 & 2005 & 4 & 0 & 0 & 0 \\
\hline 5 & 2005 & 5 & 3 & 0 & 0 \\
\hline 6 & 2005 & 3 & 0 & 0 & 0 \\
\hline 7 & 2005 & 7 & 0 & 0 & 0 \\
\hline 8 & 2005 & 5 & 0 & 0 & 0 \\
\hline 9 & 2005 & 6 & 0 & 0 & 0 \\
\hline 10 & 2005 & 4 & 2 & 0 & 0 \\
\hline 11 & 2005 & 4 & 0 & 4 & 0 \\
\hline 12 & 2005 & 4 & 4 & 4 & 1 \\
\hline 13 & 2005 & 6 & 0 & 5 & 0 \\
\hline $14^{*}$ & 2005 & 5 & 5 & 4 & 2 \\
\hline $15^{*}$ & 2005 & 6 & 3 & 5 & 1 \\
\hline 16 & 2006 & 6 & 0 & 0 & 0 \\
\hline 17 & 2006 & 5 & 3 & 3 & 0 \\
\hline 18 & 2006 & 5 & 3 & 4 & 1 \\
\hline 19 & 2006 & 0 & 0 & 4 & 0 \\
\hline 20 & 2006 & 4 & 0 & 4 & 3 \\
\hline
\end{tabular}

